\title{
The Challenges of Managing Traditional Knowledge Related to Medicinal Plants among the Batek Community in Kuala Koh, Gua Musang, Kelantan, Malaysia
}

\author{
Amran Alias, ${ }^{*}$ Hood Salleh \\ Universiti Kebangsaan Malaysia (UKM), Bangi, Malaysia
}

\begin{abstract}
The potential value of medicinal plants from the tropical rainforest resulting from the utilisation of the traditional knowledge of indigenous communities is enormous. Despite this, the indigenous communities worldwide have not been benefited much from it. In Malaysia, much has been written among other things about the usefulness and value of the knowledge of the indigenous communities. Not much however, is made known especially on how the knowledge related to medicinal plants is being managed at the indigenous community level. The objective of this paper is to describe the challenges of managing the knowledge owned by the Batek Orang Asli in Kuala Koh, Gua Musang of the State of Kelantan, Malaysia. This study employs largely an ethnographic approach of data gathering. The findings of this study among others revealed that although there is still traditional knowledge related to medicinal plants possessed by the Orang Asli, the domain and custodianship of this knowledge has generally become smaller and weaker. So are the management practice of this knowledge whereby a number of challenges in managing the knowledge have been identified including the erosion of the knowledge over time and the reluctance of the younger generations to acquire it.
\end{abstract}

Keywords: Traditional knowledge, medicinal plants, indigenous communities, knowledge management

\section{Introduction}

At the Earth Summit held in Rio de Janeiro, Brazil in 1992, a document called Agenda 21 has been produced which outlined a comprehensive program of action for assuring sustainability of the environment. One of the elements critical to the successful implementation of this Agenda is 'the recognition of the contribution of indigenous people and their knowledge to quest for a sustainable future' (United Nations Conference on Environment and Development -UNCED, 1992). 20 years after the 'Earth Summit', however, concerns regarding environmental degradation that is affecting the interests of the indigenous people and their traditional knowledge still remain. The Report of the United Nations Conference on Environment and Development (UNCED) held in Rio de Janeiro on 20-22 June 2012 or commonly known as the Rio Plus 20 further reiterated this. The Rio Plus 20 Report has highlighted the importance of the conservation of biodiversity, enhancing habitat connectivity and building ecosystem resilience. The Report has also:

\footnotetext{
..recognized that the traditional knowledge, innovations and practices of indigenous peoples and local communities make an important contribution to the conservation and sustainable use of biodiversity, and their wider application can support social well-being and sustainable livelihoods. ... further recognize that indigenous peoples and local communities are often the most directly dependent on biodiversity and ecosystems and thus are often the most immediately affected by their loss and degradation'
}

The statements of the Rio Plus 20 indicate the need to give high recognition for the protection of the traditional knowledge and the indigenous people which is an important element that can contribute towards the conservation and sustainability of the world's biodiversity. The Rio Plus 20 also recognised the dependency of this group of people and their knowledge on biodiversity and the ecosystems and how affected they are by the loss and degradation of the latter. In other words, despite all the efforts by the international community's to conserve biodiversity, the threat to the erosion of the traditional knowledge owned by the indigenous communities is still enormous and thus warranted further concrete steps to be taken to prevent this knowledge from being eroded or worse, being lost forever. The indigenous people, although very small in numbers when compared to the other societies or communities of the world, play a vital role in maintaining the global biodiversity and its eco-system due to the heavy interdependence of the two. According To McLean (2010) indigenous peoples: 
:.form approximately 5\% of the world's population (between 250 to 300 million people). They manage $11 \%$ of the world's forest lands and customarily own, occupy or use $22 \%$ of the world's land surface. It has been estimated that within their lands and territories, they maintain an overwhelming $80 \%$ of the planet's biodiversity and are located in or adjacent to $85 \%$ of the worlds protected areas'.

The indigenous peoples, obviously, have played a much bigger role than their numbers have indicated in managing the world's forests. They have acted as the primary caretaker of biodiversity and the ecosystem of the world (they maintain $80 \%$ of the global biodiversity) while living in the most parts of the world's protected areas (85\%). The heavy dependent of these communities on the forest and the utilisation of its biodiversity for their daily needs has indeed shaped the accumulation of valuable knowledge that the communities have traditionally inherited for many generations from their ancestors (McLean 2010; Mohmod, 2012). In the Malaysian context, the indigenous people or the 'Orang Asli' in Malay language constitutes even a smaller percentage of the Malaysian national population compared to the percentage of indigenous population against the global total, that is merely $0.5 \%$ of total population of the country. According to the Department of Statistics of Malaysia, in 2010, the total population of Orang Asli in Peninsular Malaysia was 178,197. Similar to the indigenous peoples in other parts of the world, the Malaysian indigenous communities, due to their heavy dependence on forests in their daily lives, have accumulated a great deal of valuable knowledge especially with regards to biological resources that they have traditionally inherited from their ancestors.

The tropical rainforests, where most Orang Asli in Peninsular Malaysia resides is indeed a valuable heritage of the country. The monetary value that can potentially be derived from medicinal plants of the tropical rainforest in Malaysia is enormous. According to Elliot \& Brimacombe (1986) cited in Jantan(2008), about 1 out of 4 drugs that are used in modern medication originate from plants that are found in the rainforests. Despite this however, only less than $5 \%$ of all plants in tropical rainforests have been studied(Farnsworth and Soejarto, 1986). This indicates that there is a huge potential for further utilisation and development of medicinal plants found in tropical rainforests and the knowledge owned by the Orang Asli that can, in turn, bring back benefits, whether it is financial or non-financial, not only to the country but also the Orang Asli themselves. Despite having traditional knowledge that is highly valuable, the indigenous communities of the world have generally not been benefited much from the valuable knowledge which is also the 'asset' they owned. Hence, their lives have not been improved to the potential of what it should be if the benefit that is generated from the utilisation of the biological resources and the traditional knowledge related to it is shared equitably with them. According to Ragavan (2001), the "indigenous people," are often referred to people who are existing under relatively disadvantageous conditions. They are, in a sense, crippled economically and socially. Ragavan (2001)further illustrated that their cohesiveness as communities are damaged or threatened, and the integrity of their cultures undermined.

This is further supported by McLean(2010)who describes the indigenous communities in Asia as marginalised and vulnerable despite the region being home to the most number of indigenous population in the world. McLean(2010)describes that:

\section{'Asia is a culturally diverse region and home to the largest number of Indigenous Peoples (between 60-70\% of the world's Indigenous Peoples live in the Asia region), who are often living in border areas, and are among the most marginalized and vulnerable groups in society.'}

Similarly, in the Malaysian context, generally, the Orang Asli are also considered marginalised in many aspects of their lives despite various initiatives by the Malaysian Government to help improve their condition. For example, from the perspective of economy, the Orang Asli remain the poorest population in Malaysia, despite efforts by the government to assist them in improving their socio-economic well-being through the implementation of various projects for their benefits(Idrus, 2011). According to the Department of Orang Asli Development (Jabatan Kemajuan Orang Asli - JAKOA) cited in Idrus (2011), although the national poverty rate in 2008 has declined over the years to $6.5 \%$, more than half $(50.9 \%)$ of the Orang Asli population remain below the poverty line. In addition, $35.2 \%$ or more than one-third of the Orang Asli population is classified as hard core poor, compared to only $1.4 \%$ recorded nationally in 2008(Idrus, 2011). In short, thus far, the Orang Asli in Peninsular Malaysia, despite receiving various assistances from the government to help elevate their social and economic status remains poor if not poorer than how they were before. This is happening despite them having highly valuable knowledge related to medicinal plants that can potentially generate monetary and non-monetary returns for the 
community(Farnsworth and Soejarto, 1986; Jantan, 2008). Although the time to be taken to utilize these plants and transform them into a form that is ready to be used as medicines is both lengthy (clinical drugs for example would normally take a long period of between 10 to 15 years from an R\&D stage to a market ready) and cumbersome (not all $R \& D$ works would result in the successful production of medicines), a successful utilization of their knowledge and the sharing of the benefits with the community from its utilization would positively contribute to the uplift of their well-being and livelihood.

However, the pertinent question to ask is how the benefits (if any) accrued from the utilisation of the resources and the knowledge related to it can be shared with the relevant stakeholders. The question is how the Orang Asli and the knowledge that has been used as well as the benefits that arose from the utilisation of the resources and their knowledge were to be shared? However, before answering this question, it should be preceded by questions such as are there still traditional knowledge related to medicinal plants available in the Orang Asli community? How is this knowledge being practiced? To date, much have been written locally by scholars and researchers that indicate the variety, richness, usefulness and value of the knowledge of the indigenous communities especially the knowledge related to medicinal plants that are not only useful for the communities themselves but also to the outside communities(Lee, 1972; Ahmad, 1985; Foo, 2007; Salleh, 2009; Omar \& Man, 2010). However, not much is made known on how the traditional knowledge of the Orang Asli that has been inherited from many generations before, is managed at the community level. Therefore, not much is understood on the existing mechanism or system practiced by the community at this stage. This paper among others provides some empirical evidence on the existing state of traditional knowledge management related to medicinal plants known to the Orang Asli. Specifically, it aims to describe challenges of managing the knowledge at the local community level. Data was collected from the Batek Orang Asli in Kuala Koh, Gua Musang in the State of Kelantan, Malaysia.

\section{Methodology}

The study employed a grounded theory approach in gathering data in fieldworks which could support the notion that the identification of important elements that are crucial to the management of the knowledge related to medicinal plants owned by the Orang Asli community would help the formulation of the relevant needed interventions that can prevent their knowledge from being lost forever and at the same time, it could also assist in ensuring that benefits accrued from the utilisation of the knowledge to be appropriately shared with members of the community - hence uplift their well-being and socio-economic status. In order to achieve this, data was obtained using largely ethnographic method which is supported by activities such as in-depth interviews, participation-observation as well as document analysis. Specifically, the fieldworks particularly the ethnographic activities which were carried out in 'Orang Asli' Batek in Kuala Koh, Gua Musangin the State of Kelantan, Malaysia in the months of April to June 2014 involved in-depth interviews with a number of important members of the community, engaging in participation-observation activities as well as undertaking analysis of documents and publications written by earlier scholars and researchers on Orang Asli and their traditional knowledge.

There are 18 sub-ethnics of 'Orang Asli' in Peninsular Malaysia, who are distinguished into 3 ethnic groups namely the Negritos, the Senoi and the Proto-Malays based on their physical characteristics, linguistic affinities and cultural practices. The Batek is one of the sub-ethnics under the Negritos tribal group along with 5 others sub-ethnics of Mendrik, Jahai, Kintak, Kensiu and Lanoh. Contrary to the general perception that the all 'Orang Asli' in Peninsular Malaysia is living in a nomadic way, the fact to the matter is that it is not the case, except for the Negrito ethnic group. The Batek community who is a part of this Negrito group was chosen in this study mainly because they traditionally have basic economic activities that are typically associated with a nomadic way of life: 'hunting and gathering' of forest produce as illustrated by a number of earlier scholars(Carey, 1976; Endicott, 1979; Endicott, 1988; Endicott and Endicott, 2012). Therefore, they possess a high level of knowledge related to forests based on their intimacy with the forests and their heavy dependents on forests for their daily lives(Ibrahim, 2013). In addition, the Batek Orang Asli in Kuala Koh resides just outside the protected area of Taman Negaraor the National Park of Kuala Koh Kelantan and thus they have the privilege of 'roaming' the National Park area which is still very much 'rich' with the natural resources compared to the other forested places in Peninsular Malaysia. Therefore, based on this justification, the Batek Orang Asli in Kuala Koh, Gua Musang, Kelantan was chosen as the site for data collection.

The data that was collected were mostly descriptive and illustrative in nature whereby the respondents have providedamong others, explanation and illustration of the knowledge that they possess, how and to 
what extent have been using themwhile observations were made on the daily activities of the community to further ascertain the information obtained from the intervews as well as providing part of the 'triangulation' process of data gathering and analysis. In addition, participation-observation in their 'hunting and gathering' activities were also made to enable a more personal experience to be obtained on those activities. The in-depth interviews which were the most important source of information for the study were done to enable a more comprehensive explanation and description on the subjects or matters to be obtained. A number of informants in the community who had been selected using purposive sampling technique, were interviewed including the local headman (Batin), some adults such as the knowledgable 'elderly' men and women as well as some youths in the community were actively engaged in 'hunting and gathering' activities.

In addition, observation-participation technique was also employed as part of the triangulation process to ascertain the of the data being gathered through interviews. Through observation and participation in activities such as the 'hunting and gathering' activities being practicedby the community, it has enabled,for example, some familiarisation on the kinds of preparation to be made before, during and after getting out the forests. This includes the preparation of 'blow-pipes' and fishing rods to name a few as among the most important instruments needed for the activities how and in what kinds of actions or activities these needed. In addition, just as important as the 'maneuvering' skills while trailing and trekking into the deep forests, one's knowledge and ability is also sought in that he or she would be able to identify the types of plants that are 'believed' to be of medicinal values. All these processes has enabled the acquiring of a clearer picture on how their daily activities look like especially in identifying the knowledge related to medicinal plants that they possessed and how they being utilised in practice by the community members.

\section{Location and Selection of Study Site}

As illustrated earlier, for the purpose of collecting and analysing data for this study, the Batek Orang Asli community in Kuala Koh, Gua Musang, Kelantan was selected from among the 18 sub ethnics of Orang Asli in Peninsular Malaysia. The composition of Orang Asli in Peninsular Malaysia is rather very small, constituting only approximately $5 \%$ of Malaysia's population. According to the Department of Statistics of Malaysia, in 2010, there were 178,197 Orang Asli in Peninsular Malaysia whereby 97,856 or $54.9 \%$ of them were from the Senoi group, 75,332 (or 42.3\%) were from the Proto Malay, while only 5,009 of 2.8\% of them were the Negritos. Among the Negritos ethnic group, the Batek recorded the second highest number of population (1,447 people or representing $28.9 \%$ of the Negritos) after Jahai $(2,387$ or $47.6 \%)$ while the rest of sub ethnics under the Negrito group were Lanoh (382), Mendriq (362), Kensiu (237) and Kintak (194). The Orang Asli can be found in all states of Peninsular Malaysia except in Penang and Perlis. In 2010, Pahang recorded the highest number of Orang Asli with 67,506 (or 37.9\% of the total Orang Asli population) found residing in the state followed by Perak with 53,299 (29.9\%) and Selangor with 17,587 (9.8\%) as the top three states. This is followed by Kelantan with 13,457 Orang Asli or 7.6\% of the total Orang Asli population, Johor 13,139(7.4\%) and Negeri Sembilan 10,531 (5.9\%). The rest of states have a rather minimal number of Orang Asli with Melaka recorded 1,515 people and followed by Terengganu and Kedah with 893 and 270 Orang Asli respectively.

For the state of Kelantan where the study is carried out, out of 13,457 Orang Asli in the state, Temiar (which is grouped into the Senoi ethnic of Orang Asli) recorded the biggest number $(11,908$ or $88.5 \%$ of the total Orang Asli population in Kelantan). This is followed by Jahai (530) and Batek (504) both of which were recognised as part of the Negrito ethnic group. According to Department of Orang Asli Development or Jabatan Kemajuan Orang Asli - JAKOA(2010), the Batek Orang Asli in Kelantan can only be found in the Gua Musang District whereby all of them can be found in the area of Pos Lebir which is spread into three villages, Kuala Koh, Felda Aring and Pasir Linggi. Kuala Koh was selected as the location of the study out of these three villages of Batek Orang Asliin Gua Musang due to its closest proximity to the Kuala Koh National Park where they have been roaming around for generations. The following maps describe the site of the study in Kuala Koh, Gua Musang, in the State of Kelantan, Malaysia. (Map 1 shows the location of state of Kelantan which is on the Northeast of Peninsular Malaysia while Map 2 shows the location of Kuala Koh which is located in the Southern part of the State of Kelantan - as shown by the arrow). 
Map 1: The State of Kelantan is located in the Northeast of Peninsular Malaysia

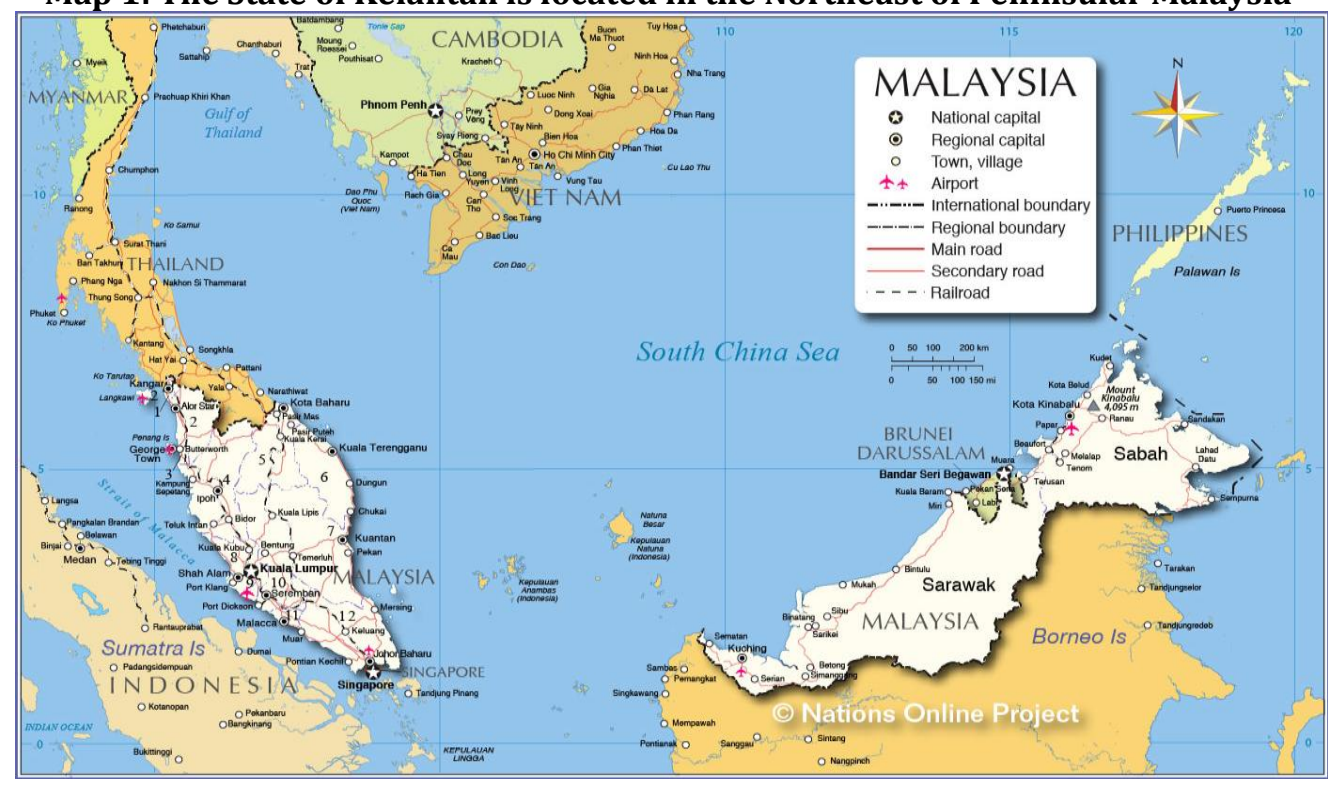

Map 2: The location of Kuala Koh in the State of Kelantan, Malaysia

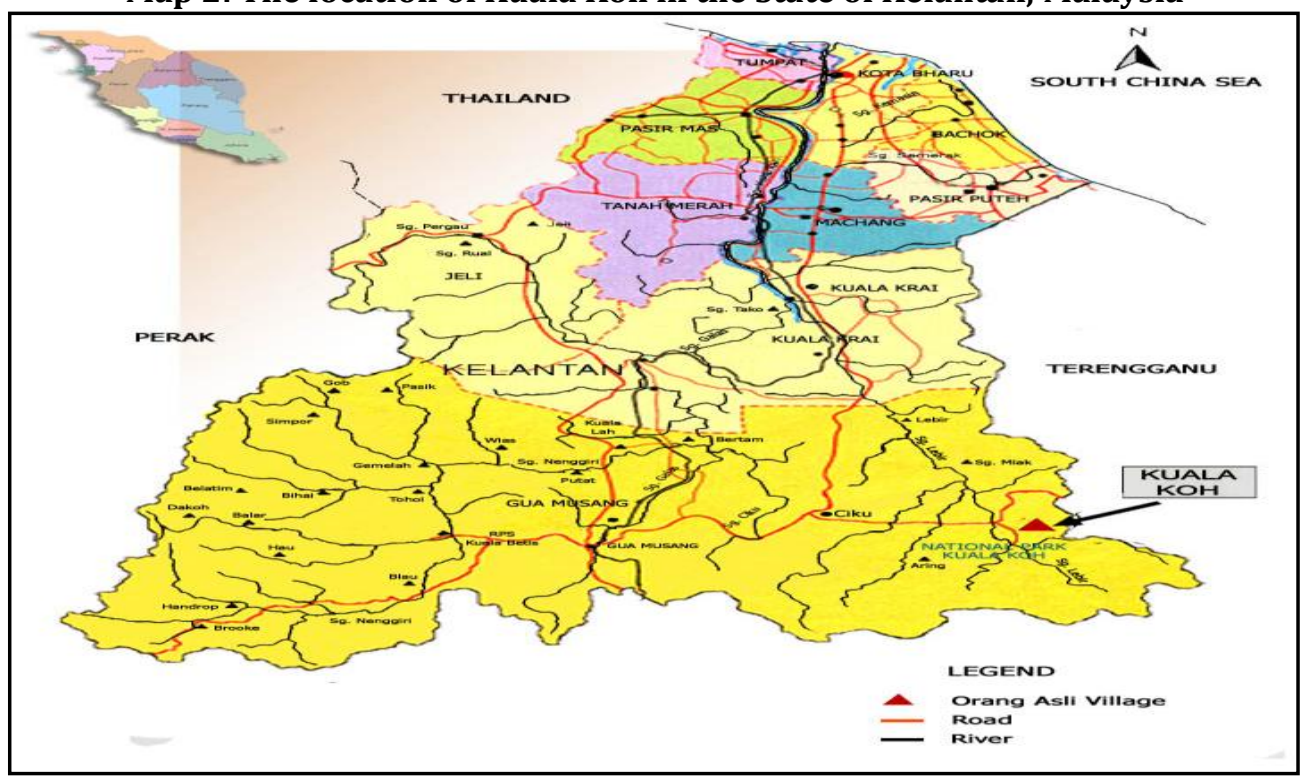

Source: (Abdullah, 2013)

\section{Findings}

This is a report in progress using largely an ethnographic approach of data gathering. Therefore, it requires an extended stay with the Orang Asli community to enable more concrete findings to be obtained. The outcomes that are presented in this paper are some of the preliminary findings of the study.

The Weakening of the Domain of the Traditional Knowledge Related to Medicinal Plants: Despite modernisation and development that has taken place in the surrounding areas where the Batek Orang Asli reside in Kuala Koh of the Gua Musang area, there is still traditional knowledge related to medicinal plants that is known and practiced by some members of the community. Based on a number of in-depth interviews with some relevant members of the Batek, it was found that in general, many of them still believe in the efficacy of the traditional medicines vis-à-vis modern medicines in curing illnesses. For example, according to the Headman, Batin Hamdan, 56, whenever a member of the community falls ill, the relevant adults or the parents or close relatives of the ill member would initially try to cure the disease themselves by obtaining the relevant medicinal plants that they can find themselves based on the advice and the teaching of a more knowledgeable member of the community. However, should this initiative 
fails, the sick person would be referred to the knowledgeable member himself and for the Batek Orang Asli of Kuala Koh, this individual is Pak Abu, 55, who inherited his knowledge and skills or ability to cure illnesses using traditional medicines from his father and ancestors. This process would involve not only direct consumption of the medicinal plants but is also commonly accompanied by the relevant rituals (also known as jampiin Malay) to be performed by Pak Abu. Based on this explanation as well as my participation in the daily activities of the community and was further supported by studies done by researchers such as Salleh (1979), there still exists varieties of knowledge related to medicinal plants that are known to 'Orang Asli's community.

The preference for the utilisation of traditional medicine for curing illnesses in the community is evidenced when Batin Hamdan shared his own experience by saying that:

'saya tak percaya kepada perubatan moden. Dulu, anak saya mati disebabkan perubatan moden. Dia ada sakit dalam perut, bila bawak ke sana(hospital) untuk berubat, tak tahu kenapa, bila balik sini dia dah mati. Kalau saya tau baik saya ubat dia sendiri.'

Translation: 'I don't really believe in modern medicine. I used to have a daughter but she died due to modern medicine. She had some stomach illness but when they brought her there (to the hospital for treatment) for the reason that I did not know she passed away. If I had known this to happen, I would have cured her myself.'

Based on his own experiences described above as well as the personal knowledge on traditional medicines that he has inherited from his ancestors as well as other members of the community such as Pak Abu, it shows that there is a strong belief in the community on the effectiveness of traditional medicines vis-à-vis modern medicines. In addition, observations on their daily lives and participation in the hunting and gathering activities have revealed that there is still much knowledge related to medicinal plants that are known to many members of the community. For instance, during one of the "hunting and gathering' activities that had been participated in, it was noticed that 'in within 500 meters of walking in between trees and bushes in one of the trails that the community were accustomed to use, there were at least 5 different plants shown by one of the member of community by which he described them as having medicinal elements to cure diseases such as headache, diarrhoea, cancer and fever to name a few'. However, it was also found that the domains and varieties of medicinal plants and the traditional knowledge related to it have declined over time. Based on the interviews and observation on the activities of their daily lives, the resources (medicinal plants) in their surrounding areas have become scarce and very difficult to obtain while the domains of the knowledge has also weakened despite fact that the Kuala Koh National Park is actually a totally protected area.

Discussion: Based on what were shared during the interviews and observation participation activities, the Batek Orang Asli seems to continue to have the knowledge about the medicinal plants especially in the forested areas of Kuala Koh National Park where they spent most of their time practising hunting and gathering activities. However, the objective of the study is mainly focusing on finding evidence that can show the availability of the traditional knowledge related to medicinal plants rather than documenting all the knowledge owned by the community as there is already efforts to document the traditional knowledge of the indigenous communities in Peninsular Malaysia particularly on medicinal plants undertaken by the Ministry of Natural Resources and Environment (NRE) through its research agency, the Forest Research Institute of Malaysia (FRIM) as a research project under the $9^{\text {th }}$ and $10^{\text {th }}$ Malaysia Plan(Pasukan Penyelidik Traditional Knowledge (TK) 2010). In addition, based on this feedback, there is also evidence to suggest that many members of the Batek Orang Asli in Kuala Koh still believe in traditional medicine as a preferred choice for curing illnesses. Not surprisingly however, this finding was also supported by a recent research by Abdullah who found more than half of the Orang Asli community under their study prefer to resort to traditional medicine as opposed to modern medicine when dealing with health problems (Abdullah, 2013). However, the richness and domain of the resources has become smaller and thus the practice of traditional knowledge related to the resources has become weaker than how it was before.

The Weakening Practice of Traditional Knowledge Management in the Community: During the indepth interviews with the relevant members of the community which include the headman (Batin), a male hunter and gatherer of the community and a number of elderly women in the community, it was revealed that there is still some sort of 'traditional system' of managing knowledge related to medicinal 
plants being practiced in the community. For example, according to the headman and supported by some elderly women in the community, they have stressed that much of the knowledge related to medicinal plants have traditionally been held by a certain individual in the community namely Pak Abu who has acquired the knowledge from his ancestors. As such, due to the nature of the transferring of the knowledge from generation to generation, some of the knowledge has also been acquired by the other members of his family which include but not limited to his wife and his siblings. Therefore, it appears that family plays an important part in identifying those with the traditional knowledge related to medicinal plants in the community. In addition, it was also found that much of the knowledge related to medicinal plants is transferred 'orally' from the elder generation to the younger one. This is based on the interviews with members of the communities especially the Batin who revealed that the traditional way of sharing knowledge in the community has always been in oral form as a medium of communication. Moreover, observations on their hunting and gathering activities have also supported their claims of 'oral transfer' of knowledge and strengthen the claim that there is a lack of written form of knowledge transfer (which mostly due to the low level of literacy among the members of the community).

Discussion: While some members of the Batek Orang Asli do possess some knowledge related to medicinal plants, this knowledge however, is generally retained by some specific members of the community as the knowledge has traditionally been inherited by the new generation mostly through familial lineage. This poses a high level of threats in terms of the sustainability of the knowledge as there is a higher possibility for the knowledge to be lost forever if it is made known only to a small percentage of the community (only to a certain family). In addition, the oral transfer of knowledge from one generation to another would require the younger members of the community the easy access to the medicinal plants that are naturally growing in the forests or around their houses. From what was observed while staying at the settlement area where the Batek Orang Asli of Kuala Koh were relocated, it could be seen that the acquiring of the knowledge related to medicinal plants by the members of the Batek is a big challenge. This is so much different from what was described by L F Dunn about the practice of traditional knowledge sharing among the members of Temiar in 1970's (Dunn, 1975). In order to learn about the medicinal plants, the members of the Batek now would have to travel a long distance deep into the protected forests of Taman Negara to gain access to those plants. In contrast, the Temiar in 1970s had found it so much easier to teach the younger generations about all aspects of the traditional knowledge related to medicinal plants which can be found in abundance just in the surrounding areas of their houses.

Another important aspect that needs to be clearly articulated is the empowerment of the community members. The nature of oral transfer of traditional knowledge practised in the community means that there is a great challenge in determining who owns which knowledge. This aspect is extremely crucial to be addressed especially in any initiatives or efforts to empower the community members in a particular initiative. Among others, it requires a clear identification of specific roles played by members of the community in the said initiative; appropriate determination of ownership; and how the benefits can be shared with the relevant members of the community. In addition, the sharing of the benefits from the utilisation of the resources and the knowledge related to it would involve addressing many relevant technical aspects which include but not limited to Intellectual Property Rights (IPR) of the resources and the knowledge; and the status of traditional knowledge vis-à-vis scientific knowledge in relation IPR to name a few, but it is not the intention of this study however to address all those. Rather, it is focusing on studying one of these components that is the in situ management of the traditional knowledge. This is to enable an understanding of how the knowledge is being practiced at the community level that would enable the identification of crucial elements in terms of the management of the traditional knowledge in the community that are significant to be considered by the relevant authorities in formulating and implementing policy and legal framework that are associated with sharing of any benefits with the indigenous communities. This is very important to the country because as of to date, Malaysia has not yet finalised and implemented a legal framework and the relevant regulations to enable a clear mechanism for benefits to be shared with the indigenous communities. (Note that the national legal framework on Access to Biological Resources and the Sharing of the Benefits from its Utilisation (ABS) is currently being finalised).

The Worsening State of Traditional knowledge Related to Medicinal Plants: Based on the interviews and through observation and participation in the activities of the Batek Orang Asli, it can be concluded that the state of traditional knowledge related to medicinal plants and the management system that is being practiced by the community has been gradually eroded over time. One of the main reasons 
identified was the reluctance of the younger generation to engage themselves in activities related to hunting and gathering that the Batek Orang Asli communities were known to have strong interests in. As Yon, 24 described:

$$
\begin{gathered}
\text { 'Budak-budak muda dah tak mau masuk dalam hutan lagi. Mungkin sebab susah nak masuk hutan dan } \\
\text { susah nak carik makanan, tumbuhan-tumbuhan ubat dan macam-macam lagi..ramai yang lagi suka } \\
\text { melepak.' }
\end{gathered}
$$

Translation: 'The youths are no longer excited to go into the forests again. It is maybe because it is more difficult to go into the forests (now) to find food, medicinal plants and others. Instead, many of them (the younger generation) prefer to just hang around and doing nothing)

In addition, based on an interview with Batin Hamdan which was further supported by Mat, 43, another member of the community who frequently engaged in hunting and gathering activities, they expressed their concerns that the knowledge that they used to have in abundance, is now diminishing from time to time mainly due to the clearance activities of some of the forests that they used to go into which has negatively impacted the availability of those medicinal plants. As Batin Hamdan pointed out:

$$
\begin{gathered}
\text { 'Dulu senang nak carik pokok-pokok atau tumbuh-tumbuhan buat ubat berbanding sekarang susah } \\
\text { sikit.Banyak kawasan hutan dah kena tebang.' }
\end{gathered}
$$

Translation: 'It used to be easier to get access to medicinal trees and plants. But now it is more difficult. It can be seen that there is a lot of forested areas have actually been cleared.'

The clearance of the forests in the area was clearly evidence as during my stay with the Batek Orang Asli, there was a hill that was completely 'cleared' just within 100 meters from their resettlement area. This has directly caused the forested areas to be reduced and the resources especially the medicinal plants that were abundant before to be scarce and difficult to obtain. This in turn has caused the utilisation of the medicinal plants and the knowledge associated to it to also decline which in turn would weaken the traditional system of managing the traditional knowledge.

Discussion: The reluctance of the younger generation of Batek Orang Asli of Kuala Koh to continue learning the knowledge that has been traditionally inherited by their elder generation could not have provided a better example of how knowledge including languages that describe those knowledge to be lost forever. It is estimated that there are more than 7,000 languages in the world, of which, more than 4,000 or almost $60 \%$ are spoken by indigenous communities and it was predicted that most of those languages would lost by the year 2020 (McLean, 2010). Based on interviews and observation, another reason that could explain the reluctance of the younger generations to engage in hunting and gathering activities was due to either exposure to activities from the nearby outside community or the change in the attitudes of the youngsters and their (un)willingness to continue doing activities that their ancestors have traditionally inherited. However, this needs a further research to ascertain it.

\section{Conclusion}

The traditional knowledge related to medicinal plants owned by the indigenous communities is highly valuable and could bring profitable returns to them if an appropriate and effective benefit sharing mechanism is in place. In the absence of much needed information about the management practice of the traditional knowledge of the Orang Asli especially in Malaysia, it is imperative to have a clear picture of how traditional knowledge is currently being managed at the Orang Asli community level. The information among others would enable the relevant authorities to identify the crucial elements to be considered in formulating and implementing the relevant initiatives and policies that are aimed at protecting the interest of this community or provide the necessary interventions on improving the existing policies or initiatives in placed. In addition, the information could also be useful to be shared with the Orang Asli community themselves so that they are aware of the existing state of their traditional knowledge. The study found that there is still much knowledge owned by the community, there are a number of challenges of managing the traditional knowledge at the Orang Asli community level which include among others, the weakening of the domain of the traditional knowledge related to medicinal plants, the weakening practice of traditional knowledge management in the community and the worsening state of traditional knowledge related to medicinal plants. The relevant authorities 
therefore, should take this, among other things, into consideration in as part of the overall efforts to address the socio-economic well-being of the community that hopefully can help bring them out of the poverty level that they are currently in.

\section{References}

Abdullah, R. (2013). Traditional Medicine Practices Among The Orang Asli In Malaysia : Batek Tribe Case At Kuala Koh, Kelantan. Second International Symposium on Business and Social Science (ISBSS). Asia-Pacific Education and Research Association, Osaka, Japan.

Ahmad, F. (1985). Medicinal Plants Used by Kadayan Community in Sarawak. The Sarawak Museum Journal, 65(2).

Carey, I. (1976). The Orang Asli: The Aboriginal Tribes of Peninsular Malaysia. Kuala Lumpur, Oxford University Press.

Dunn, L, F. (1975). Rainforest Collectors and Traders: A Study of Resource Utilisation in Modern and Ancient Malaya. Kuala Lumpur.

Endicott, K. (1979). Batek Negrito Religion. Oxford, Clarendon Press.

Endicott, K. (1988). Property, power and conflict among the Batek of Malaysia. Hunters and gatherers, 2, 110-127.

Endicott, K. M. \& Endicott, K. L. (2012). The Headman was a Woman: The Gender Egalitarian Batek of Malaysia. Subang Jaya, Malaysia, Center for Orang Asli Concerns.

Farnsworth, N. \& Soejarto, D. (1986). Pharmacy Needs Tropical Forests. Manufacturing Chemists, 3, 31-34.

Foo, J. (2007). Inventori dan Teksonomi Tumbuhan Ubatan di Persekitaran Tanah Bencah: Kajian Kes di Kampung Libang, Ranau, Sabah. Fakulti Sains Sosial dan Kemasyarakatan. Bangi, Universiti Kebangsaan Malaysia, Masters.

Ibrahim, M. A. (2013). Pengetahuan Tradisi Berkaitan Pemakanan Masyarakat Orang Asli Suku Kaum Batek, Kuala Koh, Gua Musang, Kelantan, University Sultan Zainal Abidin, Masters.

Idrus, R. (2011). The Discourse Of Protection And The Orang Asli In Malaysia."Kajian Malaysia, 29(1), 5374.

Jantan, I. (2008). Penyelidikan Tumbuhan Ubatan: Penemuan dan Pembangunan Dadah dan Produk Herba. Bangi, Selangor, Penerbit Universiti Kebangsaan Malaysia.

Jabatan Kebajikan Orang Asli (JKOA). (2010). Annual Report - Johor, Kelantan and Terengganu States Report. Kuala Lumpur.

Lee, F. E. (1972). The Ethnobotany of the Orang Asli, Malaysia, With Special Reference to Their Foodcrops, University of Malaya.

McLean, K. G. (2010). Advance Guard: Climate Change Impacts, Adaptation, Mitigation and Indigenous Peoples - A Compendium of Case Studies. Darwin, Australia, United Nations University Traditional Knowledge Initiative.

Mohmod, A. L. (2012). Forestry and Forestry Research - Contributing to Greening the Asia Pacific. International Conference on Traditional Forest-related Knowledge and Culture for Green Economy, Yangling, China.

Omar, M. \& Man, Z. (2010). Tumbuh-Tumbuhan Ubatan Orang Asli. UKM, Bangi, Selangor, Maha Ulung Holdings Sdn. Bhd.

Pasukan Penyelidik Traditional Knowledge (TK), F. R. I. o. M. F. (2010). Pendokumentasian Pengetahuan Tradisi (TK) di kalangan Orang Asli Semenanjung Malaysia. Seminar Pengetahuan Tradisi Kebangsaan 2010. FRIM, Kepong, Malaysia.

Ragavan, S. (2001). Protection of Traditional Knowledge. Minnesota Intellectual Property Review, 2(2), 160.

Salleh, H. (1979). Teori Jampi: Satu Kajian Empiri. Jabatan Antropologi dan Sosiologi, Universiti Kebangsaan Malaysia.

Salleh, H. (2009). Health and Beauty From the Rainforest: Malaysian Traditions of Ramuan. Singapore. 